\title{
Soluble ST2 in Predicting Adverse Outcome after Revascularization with Percutaneous Coronary Intervention in Patients with ST-Elevation Myocardial Infarction
}

\author{
ST-Yükselmeli Miyokard Enfarktüslü Hastalarda Perkütan Koroner Girişim ile Revaskülarizasyon \\ Sonrası Advers Sonucu Öngörmede Çözünür ST2
}

\author{
Mykola KOPYTSYA ${ }^{1}$ \\ (D) 0000-0003-4779-7347 \\ Yaroslava HILOVA ${ }^{1}$ \\ (D) 0000-0002-4545-3009 \\ Yuliia RODIONOVA ${ }^{1}$ \\ (i) 0000-0001-8438-9401 \\ Igor POLIVENOK ${ }^{2}$ \\ (i) 0000-0002-0922-1534 \\ Borys SHELEST ${ }^{3}$ \\ (D) 0000-0001-5528-8302
}

\begin{abstract}
Aim: The aim of the study was to investigate the relationship between the soluble suppression of tumorigenicity 2 (sST2) level and the degree of epicardial blood flow recovery in patients with myocardial infarction with ST-segment elevation (STEMI) after percutaneous coronary intervention.

Material and Methods: The study involved 61 patients (83.6\% males), with a mean age of $59.85 \pm 10.01$ years. SST2 level was measured by enzyme immunoassay. Patients were divided into two groups. The first group $(n=12)$ included patients with thrombolysis in myocardial infarction (TIMI) $\leq$ II flow grade, the second group $(\mathrm{n}=49)$ with TIMI III flow grade.

Results: The sST2 level was significantly higher in the first hours of the disease in the group with decreased epicardial blood flow (TIMI $\leq$ II) after percutaneous coronary intervention $(p=0.003)$. Receiver operating characteristics curve analysis showed that sST2 levels over $34.2 \mathrm{ng} / \mathrm{ml}$, detected on admission, was an independent predictor of adverse revascularization (TIMI $\leq$ II) in patients with STEMI with a sensitivity of $92.3 \%$ and a specificity of $62.5 \%$; the area under curve was $0.811(95 \% \mathrm{CI}: 0.651-0.873 ; \mathrm{p}=0.001)$. Both the univariate (OR: $1.020,95 \% \mathrm{CI}$ : 1.001-1.041, $\mathrm{p}=0.028)$ and multivariate (OR: 1.030; 95\% CI: 1.002-1.057; $\mathrm{p}=0.033$ ) analyzes showed that SST2 was a significant predictor of the unfavorable outcome of epicardial vascular revascularization (TIMI $\leq$ II).

Conclusion: sST2 is highly associated with the degree of blood flow recovery after percutaneous coronary intervention in patients with STEMI and is of great clinical importance as a prognostic marker.

Keywords: Acute myocardial infarction; sST2; no-reflow phenomenon; percutaneous coronary intervention.
\end{abstract}

${ }^{1}$ Government Institution "L.T. Malaya Therapy National Institute of the of Ukraine", Kharkiv, Ukraine

${ }^{2}$ Department of Interventional Cardiology and Cardiac Intensive Care, Zaitcev Institute for General and Urgen Surgery, National Academy of Medical Sciences of Ukraine, Kharkiv, Ukraine ${ }^{3}$ Department of Internal and Occupational Diseases, Kharkiv National Medical University, Kharkiv, Ukraine

\section{Corresponding Author Sorumlu Yazar Yuliia RODIONOVA jv.rodionova.26@gmail.com}

Received / Geliş Tarihi : 03.03.2021 Accepted / Kabul Tarihi : 12.07.2021 Available Online /

Çevrimiçi Yayın Tarihi : 26.07.2021

\section{öz}

Amaç: Bu çalışmanın amacı, ST-segment yükselmesi (STEMI) olan miyokard enfarktüslü hastalarda perkütan koroner girişim sonrası tümörijenisitenin çözünür baskılanması 2 (soluble suppression of tumorigenicity 2, sST2) seviyesi ile epikardiyal kan akımının düzelme derecesi arasındaki iliş̧inin araştırılmasıdır.

Gereç ve Yöntemler: Çalışmaya ortalama yaşı $59.85 \pm 10.01$ yıl olan 61 hasta (\%83,6 erkek) dahil edildi. SST2 seviyesi enzim immunoassay ile ölçüldü. Hastalar iki gruba ayrıldı. Birinci grup $(n=12)$ miyokard enfarktüsünde tromboliz (thrombolysis in myocardial infarction, TIMI) $\leq$ II akım dereceli hastaları, ikinci grup $(n=49)$ ise TIMI III akım dereceli hastaları içeriyordu. Bulgular: Epikardiyal kan akımı azalmış (TIMI $\leq \mathrm{II}$ ) olan grupta perkütan koroner girişim sonrası hastalığın ilk saatlerinde sST2 düzeyi anlamlı olarak daha yüksekti $(\mathrm{p}=0.003)$. Alıcı işlem karakteristiği eğrisi analizi, başvuru sırasında saptanan $34,2 \mathrm{ng} / \mathrm{ml}$ 'nin üzerindeki sST2 düzeylerinin, STEMI hastalarında $\% 92,3$ duyarlılık ve $\% 62,5$ özgüllük ile advers revaskülarizasyonun (TIMI $\leq \mathrm{II})$ bağımsız bir ön gördürücüsü olduğunu göstermiştir; eğri altında kalan alan 0,811 (\%95 GA: 0,651 - 0,873; $\mathrm{p}=0,001)$ idi. Hem tek değişkenli (OR: 1,020; \%95 GA: 1,001-1,041; $\mathrm{p}=0.028$ ) ve hem de çok değişkenli (OR: 1,030; \%95 GA: 1,002-1,057; $\mathrm{p}=0.033$ ) analizler sST2'nin epikardiyal vasküler revaskülarizasyonun olumsuz sonucunun (TIMI $\leq \mathrm{II})$ anlamlı bir ön gördürücüsü olduğunu gösterdi.

Sonuç: sST2, STEMI olan hastalarda perkütan koroner girişim sonrası kan akımındaki iyileşme derecesi ile yüksek oranda ilişkilidir ve prognostik bir belirteç olarak büyük klinik öneme sahiptir.

Anahtar kelimeler: Akut miyokard enfarktüsü; sST2; no-reflow fenomeni; perkütan koroner girişim. 


\section{INTRODUCTION}

Acute coronary syndrome (ACS) continues to be among the most significant causes of death worldwide, which is clearly seen in developed countries. Despite the introduction of high-tech interventions, the use of new highly effective drugs and an increase in public awareness of the need to seek early medical care, mortality remains high. Percutaneous coronary intervention (PCI) restores blood flow in infarction-dependent artery in patients with acute myocardial infarction (AMI), making a significant contribution to the regression of disease symptoms and improving a prognosis. However, the effectiveness of stenting of subepicardial arteries is not $100 \%$ always. It is considered that the no-reflow phenomenon is among the reasons for this, which reduces the beneficial effects of PCI. The no-reflow phenomenon is defined as insufficient myocardial perfusion that persists despite a mechanically open infarction-dependent artery. The frequency of the no-reflow phenomenon varies and reaches 50\%, depending on the assessment methods, especially in patients with ACS (1). There are studies that show that this phenomenon is associated with a poor prognosis, such as increased hospital and long-term mortality, and progression of heart failure (HF) $(2,3)$ The thrombolysis in myocardial infarction (TIMI) scale is used to assess the degree of blood flow restoration in the infarction-related artery. It is of great importance to identify new sustainable markers that can predict the unfavorable course of revascularization.

Soluble suppression of tumorigenicity 2 (sST2) can be considered as the newest marker, and it is a member of the IL-1 family. It plays an important role in myocardial remodeling and inflammation processes (4). It has been shown that sST2 levels are increased in cardiovascular stress and myocardial fibrosis $(5,6)$. sST2 competitively binds to IL-33 and blocks its positive effect on the myocardium, causing fibrosis and myocardial hypertrophy (7). There are some studies that show sST2 as an independent predictor of mortality in patients with ACS, both in the short and in the long term $(8,9)$. The relationship between high sST2 levels and adverse cardiovascular events in patients with AMI has been established (10). Recent data suggest sST2 as a promising prognostic marker in heart failure (11). There are findings showing that SST2 in contrast to the rest of heart biomarkers is linked to cardiac remodeling irrespective of renal function (12).

Herewith, the prognostic value of sST2 in the prognosis of an unfavorable course of revascularization in patients with AMI with ST-segment elevation has not yet been sufficiently studied. In our study the relationship between sST2 levels and unfavorable outcomes of revascularization in patients with ST-elevation myocardial infarction (STEMI) after PCI was analyzed.

The purpose of the study was to find out the relationship between the level of sST2 and the degree of epicardial blood flow restoration in patients with ST-elevation myocardial infarction after PCI.

\section{MATERIAL AND METHODS}

The study involved 61 patients with AMI with ST segment elevation, among them $51(83.6 \%)$ male and $10(16.4 \%)$ female, with a mean age of $59.85 \pm 10.01$ years. The patients were hospitalized and examined during the first hours of the disease. The adverse event was considered as coronary flow TIMI $\leq$ II after PCI.

The study was conducted at the Department of Prevention and Treatment of Emergency Conditions in Government Institution "L.T. Malaya Therapy National Institute of the National Academy of Medical Sciences of Ukraine", Kharkiv, between 2016 and 2017.

The diagnosis of AMI was established on the basis of data from clinical, electrocardiographic and biochemical studies in accordance with the European guidelines for the diagnosis and treatment of AMI with ST segment elevation, 2017 (13).

The studies were carried out in accordance with the provisions of the Declaration of Helsinki. The study protocol was approved by the Ethics and Deontology Commission (№ 12 from 21.10.2015). Each patient signed an informed consent to participate in the study.

Clinical and biochemical parameters were determined in all patients on the first day of the disease. Additionally, the level of sST2 was determined by the enzyme immunoassay using the Presage ST2 Assay reagent kit, Critical Diagnostics (USA) and NT-proBNP using the NTproBNP-ELISA-BEST kit (Russia). Immunoassay studies (sST2, NT-proBNP, troponin I) were carried out on an Immunochem-2100 enzyme immunoassay analyzer (USA), head. No. 501322057FSE. Echocardiographic examination was carried out using the Medison SonoAceX6 apparatus (Korea), end-systolic volume (ESV), end-diastolic volume (EDV) of the left ventricle (LV), LV diastolic dysfunction were assessed the maximum early diastolic filling velocity $E(\mathrm{~m} / \mathrm{s})$, maximum speed of atrial diastolic filling $A(\mathrm{~m} / \mathrm{s})$, their ratio $\mathrm{E} / \mathrm{A}$ and $\mathrm{LV}$ ejection fraction $(\mathrm{EF})$ according to Simpson method.

Patients received therapy in accordance with the current recommendations of the European Society of Cardiology during the entire period of treatment (13).

Inclusion criteria in the study were: patients with AMI with ST-segment elevation, hospitalization within 24 hours after the onset of the disease, age $\geq 50 \leq 75$ years, signed informed consent to participate in the study.

Exclusion criteria were refused informed consent, infectious and inflammatory diseases in the acute stage, glomerular filtration rate (GFR) $<60 \mathrm{ml} / \mathrm{min} / 1.73 \mathrm{~m}^{2}$, acute liver failure, type 1 diabetes mellitus, hypertrophic cardiomyopathy, life-threatening arrhythmias, thyroid disease, severe obesity (body mass index, BMI >35 $\mathrm{kg} / \mathrm{m}^{2}$ ), arrhythmias, inability to follow the study protocol, and patient's discontinue at any stage of the study.

Sample size were calculated with help of online sample calculator http://www.raosoft.com/samplesize.html, with margin of error accepted $10 \%$, confidence level of $95 \%$, the size of all performed PCI in the center of 200, the recommended sample size was 66 patients.

\section{Statistical Analysis}

Statistical processing of the obtained data was carried out using the statistical software Statistica 10.0 (StatSoft Inc, USA), Microsoft Office Excel 2013. Shapiro-Wilk test was used to test normality of distribution. Indicators were presented as median (interquartile range, IQR) [min-max] in descriptive statistics, taking into account the different from the normal distribution of variables. Categorical 
variables were given as percentages. Intergroup differences in qualitative characteristics were assessed using a non-parametric test, Mann-Whitney $U$ test. The Kruskal-Wallis test was used to compare more than two independent groups. Two-sided p-value of Fisher's exact test was used for categorical variables comparison. The determination of optimal cut-off value of $\mathrm{sST} 2$ to distinguish the degree of blood flow restoration in the infarction-related artery was performed by the receiver operating characteristics (ROC) curve analysis. In order to find independent predictors of degree of blood flow restoration in the infarction-related artery (TIMI score) logistic regression analysis was used. Possible confounding factors were analyzed in univariate regression analysis and confounders with a $p$ value of $<0.1$ were tested in multivariate logistic regression analysis. A $\mathrm{p}$ value of $<0.05$ was accepted as statistically significant.

\section{RESULTS}

The patients were divided into two groups depending on the degree of blood flow restoration in the infarctiondependent artery (TIMI): the first group $(n=12)$ included patients with TIMI 0 , I, II, the second group $(n=49)$ with TIMI III. Table 1 presents the baseline clinical characteristics of patients with STEMI who participated in the study. As it comes from Table 1, the both groups divided by blood flow recovering were matched by all baseline parameters; sex, age, presence of arterial hypertension, diabetes mellitus type 2 and hypercholesterolemia, smoking state, BMI, kidney function and STEMI localization. Examined initial levels of biomarkers troponin I peak and NT-pro BNP were also statistically similar in the groups, in contrast to this the sST2 values differed significantly $(81.39$; $95 \%$ CI: $38.53-$ $136.19 \mathrm{ng} / \mathrm{mL}$ vs 29.26 ; $95 \%$ CI: $22.77-52.78 \mathrm{ng} / \mathrm{mL}$; $\mathrm{p}=0.003$ ). Herewith, there were significant differences in percentage of patients with infarction-dependent artery: patients with TIMI III were prevalent with left main coronary artery ( $0 \%$ vs $49 \%, p=0.002)$, but those with TIMI $\leq 2$ with left anterior descending artery $(47.1 \%$ vs $6.1 \%, \mathrm{p}=0.001)$. Right main coronary artery and first diagonal (D1) artery of the left anterior descending artery were involved without statistical differences in proportions, $\mathrm{p}=1.000$ and $\mathrm{p}=0.357$, respectively.

The data presented in Table 2 evidence statistically similar of majority hemodynamic and ultrasound values in both groups. It should be marked that there was a significant difference between TIMI groups just in systolic blood pressure (SBP, $\mathrm{p}=0.029)$ and $\operatorname{LVEF}(\mathrm{p}=0.041)$. Aside from that, the rest investigated parameters: heart rate, diastolic blood pressure (DBP), left atrium (LA), left ventricular end-diastolic volume (LVEDV), left ventricular endsystolic volume (LVESV), the ratio (E/A) of mitral peak velocity of early filling (the $E$ wave) to mitral peak velocity of late filling (the A wave), left ventricle mass (LVM) did not demonstrated significant differences.

There were also analyzed the differences in SST2 and NTpro BNP levels in dependence of occlusion localizations with the aim to find out the possible association between biomarker values and occlusion localizations - right main

Table 1. Baseline characteristics of patients with STEMI

\begin{tabular}{|c|c|c|c|}
\hline & Patients with TIMI 0-II (n=12) & Patients with TIMI III $(n=49)$ & $\mathbf{p}$ \\
\hline \multicolumn{4}{|c|}{ Demographic parameters and risk factors } \\
\hline Age (years) & $62.7(17.5)[52-74]$ & $57.2(14.0)[50-75]$ & 0.104 \\
\hline Males, n (\%) & $10(83.3 \%)$ & $41(83.7 \%)$ & 1.000 \\
\hline Arterial hypertension, $\mathrm{n}(\%)$ & $11(91.7 \%)$ & $34(69.4 \%)$ & 0.156 \\
\hline Diabetes mellitus type $2, \mathrm{n}(\%)$ & $1(8.3 \%)$ & $12(24.5 \%)$ & 0.432 \\
\hline Smoking, n (\%) & $8(66.7 \%)$ & $19(38.8 \%)$ & 0.109 \\
\hline Hypercholesterolemia, n (\%) & $8(66.7 \%)$ & $34(69.4 \%)$ & 1.000 \\
\hline Body mass index $\left(\mathrm{kg} / \mathrm{m}^{2}\right)$ & $29.57(4.45)[26.30-34.51]$ & $30.07(5.91)[21.97-35.00]$ & 0.863 \\
\hline GFR CKD-EPI (ml/min/1.73m²) & $79.13(23.07)[61.45-119.82]$ & $78.03(31.26)[60.06-135.42]$ & 0.498 \\
\hline \multicolumn{4}{|l|}{ STEMI localization, n (\%) } \\
\hline Anterior MI & $7(58.3 \%)$ & $23(46.9 \%)$ & 0.534 \\
\hline Posterior MI & $5(41.7 \%)$ & $22(44.9 \%)$ & 1.000 \\
\hline Other & $0(0.0 \%)$ & $3(6.1 \%)$ & 1.000 \\
\hline \multicolumn{4}{|l|}{ Number of affected vessels, $n(\%)$} \\
\hline 1 vessel & $2(16.7 \%)$ & $10(20.4 \%)$ & 1.000 \\
\hline 2 vessels & $4(33.3 \%)$ & $11(22.4 \%)$ & 0.467 \\
\hline 3 vessels & $0(0.0 \%)$ & $16(32.7 \%)$ & 0.028 \\
\hline \multicolumn{4}{|l|}{ Infarction-dependent artery, n (\%) } \\
\hline Left main coronary artery & $0(0.0 \%)$ & $24(49.0 \%)$ & 0.002 \\
\hline Left anterior descending artery & $6(50.0 \%)$ & $3(6.1 \%)$ & 0.001 \\
\hline Right main coronary artery & $5(41.7 \%)$ & $21(42.9 \%)$ & 1.000 \\
\hline D1 Left anterior descending artery & $1(8.3 \%)$ & $1(2.0 \%)$ & 0.357 \\
\hline \multicolumn{4}{|l|}{ Biomarkers' level } \\
\hline Troponin I peak (ng/ml) & $32.4(32.6)[8.8-51.0]$ & $22.4(17.8)[9.2-49.8]$ & 0.446 \\
\hline $\mathrm{sST} 2(\mathrm{ng} / \mathrm{ml})$ & 81.39 (98.19) [20.94 - 319.12] & $29.26(30.01)[13.05-155.70]$ & 0.003 \\
\hline NT-proBNP (pg/ml) & $232.87(275.51)[62.67-415.83]$ & $247.54(268.86)$ [55.99 - 431.67] & 0.668 \\
\hline
\end{tabular}


Table 2. Hemodynamic and ultrasound parameters in patients with STEMI

\begin{tabular}{lccc}
\hline Indices & Patients with TIMI 0-II (n=12) & Patients with TIMI III (n=49) & p \\
\hline Heart rate (per min) & $70(27.5)[38-100]$ & $76(20.0)[44-115]$ & 0.617 \\
SBP (mm Hg) & $145.5(30.5)[110.0-175.0]$ & $130.0(17.5)[100.5-155.0]$ & $\mathbf{0 . 0 2 9}$ \\
DBP (mm Hg) & $85.0(15.2)[55.0-100.5]$ & $83.5(22.5)[60.0-110.0]$ & 0.325 \\
LA (cm) & $4.2(0.8)[3.0-5.5]$ & $3.9(0.8)[3.1-5.3]$ & 0.322 \\
LVEDV (ml) & $136.5(62.5)[89.0-196.0]$ & $126.0(39.0)[90.5-180.0]$ & 0.480 \\
LVESV (ml) & $69.8(35.2)[40.0-102.5]$ & $65.1(29.5)[35.0-104.5]$ & 0.328 \\
LVEF $(\%)$ & $48.7(12.0)[45.0-59.0]$ & $53.5(11.7)[45.0-73.5]$ & $\mathbf{0 . 0 4 1}$ \\
E/A & $1.08(0.70)[0.59-1.75]$ & $1.22(0.39)[0.67-2.39]$ & 0.163 \\
LVM (gr) & $263(64)[150-354]$ & $239(79)[105-390]$ & 0.414 \\
\hline STE
\end{tabular}

STEMI: ST-elevation myocardial infarction, TIMI: thrombolysis in myocardial infarction, SBP: systolic blood pressure, DBP: diastolic blood pressure, LA: left atrium, LVEDV: left ventricular end-diastolic volume, LVESV: left ventricular end-systolic volume, LVEF: left ventricle ejection fraction, E/A: the ratio of mitral peak velocity of early filling (the E wave) to mitral peak velocity of late filling (the A wave), LVM: left ventricle mass, descriptive statistics were presented as median (interquartile range) [min-max].

coronary artery, left anterior descending artery, D1 artery of the left anterior descending artery, left main coronary artery. The Kruskal-Wallis test indicated no significant difference in the levels of the both studied biomarkers sST2 and NT-proBNP in dependence of the infarctdependent coronary artery $(\mathrm{p}=0.687)$. When analyzing the level of sST2 in the studied patients, it was found that its level was significantly higher in the first hours of the disease in the group with unrecovered or decreased epicardial blood flow (TIMI $\leq \mathrm{II})$ after PCI $(\mathrm{p}=0.003)$.

The receiver operating characteristics (ROC) curve analysis was used for determination of optimal cut-off value of sST2 for the prediction revascularization degree (TIMI 0-II). During the ROC analysis, it was found that the sST2 level above $34.20 \mathrm{ng} / \mathrm{ml}$, determined in the first hours of the disease, is suggested to be a possible biomarker for distinguishing TIMI $\leq$ II from TIMI $>$ II in patients with STEMI with a sensitivity of $92.3 \%$ and a specificity of $62.5 \%$; the area under the AUC curve was 0.811 (95\% CI: $0.651-0.873 ; \mathrm{p}=0.001$ ).

Univariate and multivariate logistic regression analyses were performed to study independent predictors of the adverse outcome of revascularization indicated as TIMI level degree. When conducting univariate regression analysis it was found that sST2 level (OR: 1.020, 95\% CI: $1.001-1.041, \mathrm{p}=0.028$ ); SBP (OR: 1.083, 95\% CI: 1.036 - 1.151, $\mathrm{p}=0.011$ ); LVEDV (OR: 0.776, 95\% CI: $0.511-0.983, \mathrm{p}=0.039$ ); LVESV (OR: 0.675, 95\% CI: $0.351-0.997, \mathrm{p}=0.042$ ); and EF (OR: 1.011, 95\% CI: 1.003 - 1.263, p=0.017) were independent confounding factors for unfavorable outcome of epicardial revascularization (TIMI 0-II). The multivariate logistic regression analysis which included confounders with a $\mathrm{p}$ value of $<0.1$ obtained from univariate logistic regression analysis indicated that $\mathrm{sST} 2$ remained as significant predictor of TIMI 0-II by PCI in patients with STEMI (OR: 1.030; 95\% CI: 1.002 - 1.057; $\mathrm{p}=0.033)$ as is shown in Table 3 .

\section{DISCUSSION}

It can be highlighted three main findings of our study. First, the values of sST2 in STEMI patients with TIMI $\leq$ II were significantly higher than that of TIMI >II patients. Second, sST2 is independent predictor for the development of adverse revascularization in patients with STEMI after PCI treatment. At last, high sST2 levels on admission evidence on increased risk for no-reflow
Table 3. Univariate and multivariate logistic regression analysis of the influence of the studied factors on the TIMI score $(\leq \mathrm{II})$ in patients with STEMI after PCI

\begin{tabular}{|c|c|c|}
\hline Indices & OR $(95 \%$ CI $)$ & $\mathbf{p}$ \\
\hline \multicolumn{3}{|c|}{ Univariate logistic regression } \\
\hline $\mathrm{sST} 2, \mathrm{ng} / \mathrm{ml}$ & $1.020(1.001-1.041)$ & 0.028 \\
\hline $\mathrm{SBP}(\mathrm{mm} \mathrm{Hg})$ & $1.083(1.036-1.151)$ & 0.011 \\
\hline $\mathrm{DBP}(\mathrm{mm} \mathrm{Hg})$ & $1.029(0.889-1.076)$ & 0.343 \\
\hline Gender (M/F) & $2.155(0.755-1.939)$ & 0.477 \\
\hline Age (years) & $0.989(0.961-1.023)$ & 0.949 \\
\hline BMI $\left(\mathrm{kg} / \mathrm{m}^{2}\right)$ & $1.058(0.919-1.139)$ & 0.280 \\
\hline Smoking & $3.659(0.541-29.187)$ & 0.653 \\
\hline $\mathrm{TC}(\mathrm{mmol} / \mathrm{L})$ & $0.861(0.519-1.314)$ & 0.119 \\
\hline LVEDV (ml) & $0.776(0.511-0.983)$ & $\mathbf{0 . 0 3 9}$ \\
\hline LVESV (ml) & $0.675(0.351-0.997)$ & 0.042 \\
\hline LVEF $(\%)$ & $1.011(1.003-1.263)$ & 0.017 \\
\hline \multicolumn{3}{|c|}{ Multivariate logistic regression } \\
\hline sST2, ng/ml & $1.030(1.002-1.057)$ & $\mathbf{0 . 0 3 3}$ \\
\hline $\mathrm{SBP}(\mathrm{mm} \mathrm{Hg})$ & $1.097(0.991-1.189)$ & 0.057 \\
\hline LVEDV (ml) & $0.990(0.931-1.062)$ & 0.871 \\
\hline LVESV (ml) & $0.903(0.802-1.199)$ & 0.576 \\
\hline $\operatorname{LVEF}(\%)$ & $1.845(0.948-1.291)$ & 0.633 \\
\hline
\end{tabular}

STEMI: ST-elevation myocardial infarction, TIMI: thrombolysis in myocardial infarction, PCI: percutaneous coronary intervention, OR: odds ratio, CI: confidence interval, sST2: soluble suppression of tumorigenicity 2, SBP: systolic blood pressure, DBP: diastolic blood pressure, M: male, F: female, BMI: body mass index, TC: total cholesterol, LVEDV: left ventricular end-diastolic volume, LVESV: left ventricular end-systolic volume, LVEF: left ventricle ejection fraction.

development compared with initial low sST2 levels. Our study is the first attempt to identify association between sST2 and no-reflow phenomenon in PCI-administered STEMI patients. The presented results prove that sST2 level on admission is significantly associated with no-reflow phenomenon and can be used to predict it development.

Our study possibly gave additional proof that the essential chain in the process of no-reflow is inflammation. The phenomenon of no-reflow, which is defined as incomplete reperfusion at the microvascular level, despite the complete opening of the infarction-dependent artery, which may be due to tissue edema, the presence of microthrombi, accumulation of neutrophils and the formation of free radicals, which are believed to be associated with 
inflammation after coronary perfusion (14). Potential risk factors for no-reflow are thought to be associated with inflammatory activity after AMI. Most likely, the no-reflow phenomenon prediction becoming rather difficult due to the complexity of its occurrence mechanism.

sST2 is one of the molecules that cardiomyocytes release when the myocardium is damaged. Recently, this biomarker has been included in the clinical guidelines for HF and is widely used and studied in patients with HF (15-17). The search for an association of sST2 with genetic polymorphisms in HF continues (18). Herewith its pathophysiological features in AMI have not been adequately studied, especially in terms of the no-reflow phenomenon. The existing data on the role of sST2 in AMI are contradictory $(19,20)$. In the study on mice, it was shown that the IL-33/sST2 pathway induces IL-6 and IL-8 and causes systemic inflammation (21).

In his study Tuegel et al. (22) found that in patients with renal disease with higher circulating sST2 levels have increased mortality, possibly through inflammatory, fibrotic changes and heart remodelling. Thus, this result indirectly is aligned with our preposition that higher sST2 levels give negative prognosis in patients. On the other hand, Tuegel et al. (22) did not find sST2 interconnection with heart failure or atherosclerotic CVD in multivariable models.

As we found a prognostic role of admission sST2 level in low TIMI score after PCI in STEMI patients, another investigation proved this biomarker is a possible predictor of contrast-induced nephropathy (CIN) in STEMI patients (23). Now, it can be seen that SST2 became great clinical prognostic parameter for several end-points.

Findings from European multicenter randomized placebocontrolled study (PROTECT) investigating 44 novel heart biomarkers in heart failure. It verified SST2 as a strong independent predictor all-cause mortality and cardiovascular or kidney rehospitalization (24). Therefore, we consider that our results are in correspondence with these conclusions from mentioned European study, because no-reflow can be essential reason for poor prognosis (25).

The results from our study are important due to appearance of a new predictor of no-reflow phenomenon in addition to previously described ones in Fajar et al. (26) review.

Balta et al. (27) devoted their investigation to find another new predictor of no-reflow in STEMI patients, and proved that monocyte to high density lipoprotein ratio (MHR) is an independent predictor of no reflow after pPCI. The ROC analysis from that study showed that the MHR level cut-off point was $22.5 \mathrm{ng} / \mathrm{ml}$, with a sensitivity and specificity of $70.2 \%$ and $73.3 \%$, respectively (AUC=0.768, 95\% CI: 0.725-0.811), but we showed, that sST2 with a higher sensitivity level and $11 \%$ less specificity and the closely equal AUC. Our consideration is that the both parameters can be used for no-reflow predicting, and further researches obligatory to find optimal marker or to use them simultaneously.

The purpose of our study was close to Zhao et al. (28) study. In that study they evaluated if admission fibrinogen-to-albumin ratio (FAR) values is associated with no-reflow in 510 STEMI patients. It was similar to our study, because it also specifying TIMI $\leq$ II flow grade influence on "no-reflow". Zhao et al. (28) showed that admission FAR can be considered as an independent predictor of no-reflow. ROC analysis elucidated the FAR cut-off value can predict no-reflow with a sensitivity of $79.59 \%$ and a specificity of $69.42 \%$, that was shade less than our ROC results. Zhao et al. (28) showed admission FAR value is positively associated with all-cause mortality, as well as sST2 $(22,24)$.

sST2 plays a role in the release of proinflammatory cytokines from macrophages and induces inflammation and free radical release in the acute phase of myocardial infarction and, it seems that it may be the cause of the no-reflow phenomenon in AMI patients. This is consistent from our data according to which the level of sST2 in patients with blood flow according to the TIMI $\leq$ II scale is significantly higher than in patients with TIMI III blood flow. There is a study showing the relationship of IL-6 with the phenomenon of slow coronary flow. Thus that results also impliedly accord idea that the high levels of sST2 might lead to an increase in the frequency of the phenomenon of no-reflow (29).

The study by Sabatine et al. (30) determined sST2 in patients with STEMI who underwent coronary angiography. The follow-up period was 30 days. The sST2 value was associated with a significantly greater risk of cardiovascular death or heart failure. In our study, when conducting a logistic regression analysis, $\mathrm{sST} 2$ turned out to be a significant predictor of an unfavorable outcome of revascularization in patients with AMI with ST segment elevation.

The obtained results confirm the data of studies in which the role of $\mathrm{SST} 2$ in predicting the unfavorable course of AMI was studied. Shimpo et al. (31), investigated sST2 in patients with STEMI in the TIMI 14 and TIMI 23 studies. The baseline sST2 level was significantly higher in deceased patients and in patients with heart failure developed by 30 follow-up days. When analyzing adverse events by day 30 of follow-up, both death and the combined death/HF endpoint showed a significant association with sST2 levels. Also, in-hospital mortality and death/HF were associated with higher sST2 levels. The data we obtained correspond to the available literature data - determination of sST2 over $34.2 \mathrm{ng} / \mathrm{ml}$ makes it possible to predict an unfavorable outcome of revascularization in patients with AMI with TIMI score $\leq$ II.

This study presents several limitations. First, the limitation of our study was the small sample size to achieve definitive conclusions. Another was that only one clinical center was involved. Also, it should be indicated that males were predominantly presented in the study. Additionally, it was a prevalence of the patients with TIMI III compared to those ones with TIMI $\leq$ II, hence it could intend to some statistical discordances, on the other hand, we used appropriate (non-parametric) statistical methods doing our best to avoid this. We also measured just TIMI score as outcome, without considering other possible endpoints.

Further studies are required on the role of sST2 in the pathogenesis of the no-reflow phenomenon, and the search for effective methods to prevent it. The promising for further study is the investigation of the no-reflow phenomenon with the assessment of the possible relationship of myocardial perfusion on the myocardial blush grade (MBG) scale with the studied marker. 


\section{CONCLUSION}

No-reflow is incomplete reperfusion after percutaneous intervention in STEMI patients resulting in adverse endpoints. We demonstrated that the sST2 level at admission is independently associated with the no-reflow phenomenon in STEMI patients after PCI. The sST2 level estimation is suggested to be important to prevent the no-reflow phenomenon development in STEMI patients. Further research is needed to understand the sST2 influence on decreased blood flow development and to prognosticate patients at high risk for poor outcomes.

Ethics Committee Approval: The study was approved by the Ethics Committee of Government Institution "L.T. Malaya Therapy National Institute of the National Academy of Medical Sciences of Ukraine" $(21.10 .2015,12)$.

Conflict of Interest: This manuscript was produced based on the PhD thesis of Yaroslava Hilova, and all authors declare that there is no conflict of interest.

Financial Disclosure: None declared by the authors.

Acknowledgements: None declared by the authors.

Author Contributions: Idea/Concept: MK; Design: YH; Data Collection/Processing: YH, YR; Analysis/Interpretation: IP; Literature Review: BS; Drafting/Writing: YR; Critical Review: BS.

\section{REFERENCES}

1. Durante A, Camici PG. Novel insights into an "old" phenomenon: the no reflow. Int $\mathrm{J}$ Cardiol. 2015;187(1):273-80.

2. Stone GW, Peterson MA, Lansky AJ, Dangas G, Mehran R, Leon MB. Impact of normalized myocardial perfusion after successful angioplasty in acute myocardial infarction. J Am Coll Cardiol. 2002;39(4):591-7.

3. Resnic FS, Wainstein M, Lee MK, Behrendt D, Wainstein RV, Ohno-Machado L, et al. No-reflow is an independent predictor of death and myocardial infarction after percutaneous coronary intervention. Am Heart J. 2003;145(1): 42-6.

4. Kohli P, Bonaca MP, Kakkar R, Kudinova AY, Scirica $\mathrm{BM}$, Sabatine MS, et al. Role of ST2 in non-STelevation acute coronary syndrome in the MERLINTIMI 36 trial. Clin Chem. 2012;58(1):257-66.

5. Pascual-Figal DA, Januzzi JL. The biology of ST2: the International ST2 Consensus Panel. Am J Cardiol. 2015;115(7 Suppl):3B-7B.

6. Lepojärvi ES, Piira OP, Pääkkö E, Lammentausta E, Risteli J, Miettinen JA, et al. Serum PINP, PIIINP, galectin-3, and ST2 as surrogates of myocardial fibrosis and echocardiographic left venticular diastolic filling properties. Front Physiol. 2015;6:200.

7. Weinberg EO, Shimpo M, De Keulenaer GW, MacGillivray C, Tominaga S, Solomon SD, et al. Expression and regulation of ST2, an interleukin-1 receptor family member, in cardiomyocytes and myocardial infarction. Circulation. 2002;106(23):2961-6.
8. Manzano-Fernández S, Mueller T, Pascual-Figal D, Truong QA, Januzzi JL. Usefulness of soluble concentrations of interleukin family member ST2 as predictor of mortality in patients with acutely decompensated heart failure relative to left ventricular ejection fraction. Am J Cardiol. 2011;107(2):259-67.

9. Eggers KM, Armstrong PW, Califf RM, Simoons ML, Venge P, Wallentin L, et al. ST2 and mortality in nonST-segment elevation acute coronary syndrome. Am Heart J. 2010;159(5):788-94.

10. Jenkins WS, Roger VL, Jaffe AS, Weston SA, AbouEzzeddine OF, Jiang R, et al. Prognostic value of soluble ST2 after myocardial infarction: A community perspective. Am J Med. 2017;130(9):1112.e9-15.

11. Maisel AS, Di Somma S. Do we need another heart failure biomarker: focus on soluble suppression of tumorigenicity 2 (sST2). Eur Heart J. 2017;38(30):2325-33.

12. Plawecki M, Morena M, Kuster N, Chenine L, LerayMoragues H, Joveret B, et al. sST2 as a new biomarker of chronic kidney disease-induced cardiac remodeling: Impact on risk prediction. Mediators Inflamm. 2018;2018:3952526.

13. Ibanez B, James S, Agewall S, Antunes MJ, Bucciarelli-Ducci C, Bueno H, et al. ESC Scientific Document Group. 2017 ESC Guidelines for the management of acute myocardial infarction in patients presenting with ST-segment elevation: The Task Force for the management of acute myocardial infarction in patients presenting with ST-segment elevation of the European Society of Cardiology (ESC). Eur Heart J. 2018;39(2):119-77.

14. Niccoli G, Burzotta F, Galiuto L, Crea F. Myocardial no-reflow in humans. J Am Coll Cardiol. 2009;54(4):281-92.

15. Villacorta H, Maisel AS. Soluble ST2 testing: A promising biomarker in the management of heart failure. Arq Bras Cardiol. 2016;106(2):145-52.

16. Januzzi JL, Pascual-Figal D, Daniels LB. ST2 testing for chronic heart failure therapy monitoring: The International ST2 Consensus Panel. Am J Cardiol. 2015;115(7 Suppl):70B-5B.

17. AbouEzzeddine OF, McKie PM, Dunlay SM, Stevens SR, Felker GM, Borlaug BA, et al. Suppression of tumorigenicity 2 in heart failure with preserved ejection fraction. $\mathrm{J}$ Am Heart Assoc. 2017;6(2):e004382.

18. Rudyk I, Medentseva O. [The role of marker fibrosis ST2 and angiotensinogen gene polymorphism in heart failure progressing in patients with type 2 diabetes mellitus]. Georgian Med News. 2018;2:105-12. Russian.

19. Bayes-Genis A, Zhang Y, Ky B. ST2 and patient prognosis in chronic heart failure. Am J Cardiol. 2015;115(7 Suppl):64B-9B.

20. Díez J. Serum soluble ST2 as a biochemical marker of acute heart failure: future areas of research. J Am Coll Cardiol. 2008;52(18):1466-7.

21. Wu H, Yang S, Wu X, Zhao J, Zhao J, Ning Q, et al. Interleukin-33/ST2 signaling promotes production of interleukin-6 and interleukin-8 in systemic inflammation in cigarette smoke-induced chronic 
obstructive pulmonary disease mice. Biochem Biophys Res Commun. 2014;450(1):110-6.

22. Tuegel C, Katz R, Alam M, Bhat Z, Bellovich K, de Boer I, et al. GDF-15, galectin 3, soluble ST2, and risk of mortality and cardiovascular events in CKD. Am J Kidney Dis. 2018;72(4):519-28.

23. Avc1 A, Somuncu MU, Can M, Akgul F. Could sST2 predict contrast-induced nephropathy in ST-segment elevation myocardial infarction? Int J Gen Med. 2020;13:1297-304.

24. Demissei BG, Valente MA, Cleland JG, O'Connor CM, Metra M, Ponikowski P, et al. Optimizing clinical use of biomarkers in high-risk acute heart failure patients. Eur J Heart Fail. 2016;18(3):269-80.

25. Gupta S, Gupta MM. No reflow phenomenon in percutaneous coronary interventions in ST-segment elevation myocardial infarction. Indian Heart J. 2016;68(4):539-51.

26. Fajar JK, Heriansyah T, Rohman MS. The predictors of no reflow phenomenon after percutaneous coronary intervention in patients with ST elevation myocardial infarction: A meta-analysis. Indian Heart J. 2018;70(Suppl 3):S406-18.

27. Balta S, Celik T, Ozturk C, Kaya MG, Aparci M, Yildirim AO, et al. The relation between monocyte to
HDL ratio and no-reflow phenomenon in the patients with acute ST-segment elevation myocardial infarction. Am J Emerg Med. 2016;34(8):1542-7.

28. Zhao Y, Yang J, Ji Y, Wang S, Wang T, Wang F, et al. Usefulness of fibrinogen-to-albumin ratio to predict no-reflow and short-term prognosis in patients with ST-segment elevation myocardial infarction undergoing primary percutaneous coronary intervention. Heart Vessels. 2019;34(10):1600-7.

29. Liu CL, Xue ZQ, Gao SP, Chen C, Chen XH, Pan M, et al. The relationship between interleukin- 6 promotor polymorphisms and slow coronary flow phenomenon. Clin Lab. 2016;62(5):947-53.

30. Sabatine MS, Morrow DA, Higgins LJ, MacGillivray C, Guo W, Bode C, et al. Complementary roles for biomarkers of biomechanical strain ST2 and Nterminal prohormone B-type natriuretic peptide in patients with ST-elevation myocardial infarction. Circulation. 2008;117(15):1936-44.

31. Shimpo M, Morrow DA, Weinberg EO, Sabatine MS, Murphy SA, Antman EM, et al. Serum levels of the interleukin-1 receptor family member ST2 predict mortality and clinical outcome in acute myocardial infarction. Circulation. 2004;109(18):2186-90. 